\title{
Charcot's son, commander Jean-Baptiste Charcot: from neurology to "Pourquoi Pas?"
} O filho de Charcot, comandante Jean-Baptiste Charcot: da neurologia para o "Pourquoi-Pas?" Hélio A. G. Teive', Renato P. Munhoz', Jefferson C. Simões²

\begin{abstract}
Charcot name became very famous around the world, firstly because of the work of Professor Jean-Martin Charcot, the founder of Clinical Neurology, and, secondly, because of his son, Jean-Baptiste, the world famous maritime explorer.
\end{abstract}

Key words: Charcot, neurology, Jean-Baptiste Charcot.

RESUMO

O nome Charcot tornou-se muito famoso em todo o mundo, primeiramente, por causa do trabalho do professor Jean-Martin Charcot, o fundador da Neurologia Clínica e, posteriormente, devido ao seu filho, Jean-Baptiste, o famoso explorador marítimo conhecido mundialmente.

Palavras-Chave: Charcot, neurologia, Jean-Baptiste Charcot.

Jean-Martin Charcot (from 1825 to 1893) can be considered the founder of Neurology, as well as the first and most important professor to undertake the formal study of nervous system diseases ${ }^{1-5}$.

At the age of 39, Professor Charcot married AugustineVictoire Durvis, a young widow, with whom he had one daughter, Jeanne, and one son, Jean-Baptiste Étienne Auguste Charcot (1867-1936) $)^{1,3,4}$.

As a child, Jean-Baptiste loved to go on trips to the sea, and he expressed a strong desire to enter the Naval Academy, probably influenced by his maternal uncle ${ }^{1,3,4}$.

However, Professor Jean-Martin Charcot, true to his highly authoritarian personality, opposed his son's wish and insisted that he studied Medicine. In the famous painting "Une leçon clinique à La Salpêtrière", by Louis Brouillet, Jean-Baptiste Charcot can be seen in the back row on the right (Fig 1$)^{6}$.

Here we describe some aspects of Jean-Baptiste Charcot's life, from his activities as a neurologist at La Salpêtrière Hospital to his time as the Commander Charcot, a maritime explorer who became famous worldwide.

\section{THE NEUROLOGIST}

Jean-Baptiste Charcot was born in 1867 in the town of Neuilly-sur-Seine, France, in a Summer house, which belonged to the Charcot family.

On several occasions during his childhood, he expressed an interest in becoming a maritime navigator ${ }^{1,3,4,7}$. However, his father, Professor Jean-Martin Charcot, always insisted on his becoming a doctor, and letters from Professor Charcot to his son referred to in the famous biography of Charcot by Goetz et al. confirm this: "You will become a doctor: once you have your degree, you may do what you see fit, but until that time, you do what I say"'.

Following his father's wish, Jean-Baptiste Charcot started medical school and became "Interne des Hôpitaux de Paris", in 1891, at La Salpêtrière Hospital, under the supervision of Édouard Brissaud, one of Professor Charcot's pupils ${ }^{1}$.

Two years later, in August 1893, his father suddenly died while on vacation in the Morvan, in the countryside in "L'Auberge $d u$ Lac des Settons" "1,2,7. At the time of his father's death, Jean-Baptiste was still a medical student and continued his medical career.

\footnotetext{
${ }^{1}$ Movement Disorders Unit, Neurology Service, Internal Medicine Department, Hospital de Clínicas, Federal University of Paraná, Curitiba PR, Brazil; ${ }^{2}$ Geosciences Institute, Geography Department, Federal University of Rio Grande do Sul, Porto Alegre RS, Brazil. Correspondence: Hélio A. G. Teive; Rua General Carneiro 1103/102;80060-150 Curitiba PR-Brasil; E-mail: hagteive@mps.com.br Conflict of interest: There is no conflict of interest to declare.

Received 22 October 2011; Receive in final from 10 November 2011; Accepted 17 November 2011
} 


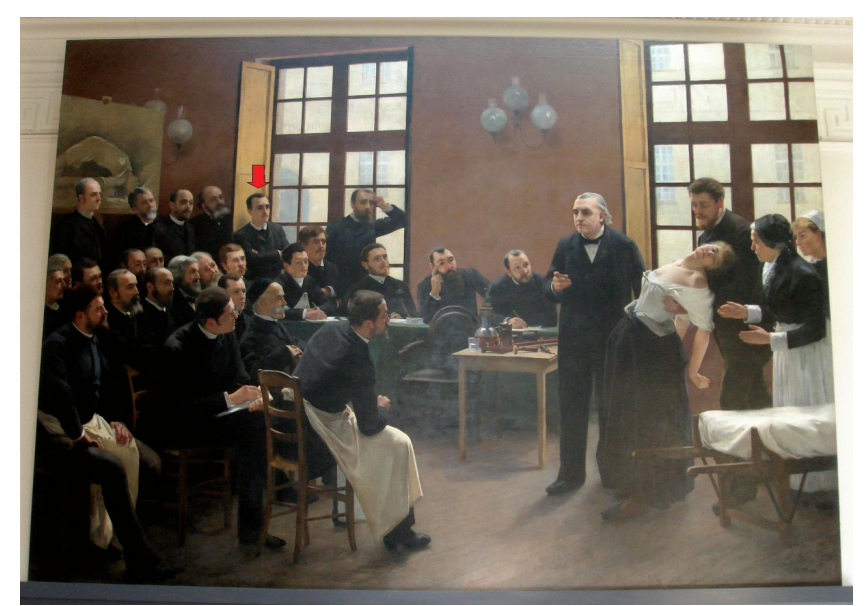

Extracted from Doctor Olivier Walusinski site, with authorization.

Fig 1. Jean-Baptiste Charcot as an intern of Professor JeanMartin Charcot a La Salpêtrière.

In 1895, Jean-Baptiste defended his doctoral thesis on progressive muscular atrophy and became Chief of Clinic under Professor Fulgence Raymond. Later, he left La Salpêtrière Hospital and went to the Pasteur Institute to study cancer ${ }^{1,2}$.

However, he subsequently decided to give up Medicine and Neurology and begin a career as a maritime explorer to pursue his first love, sailing, and the sea $a^{1,2,8,9}$.

\section{THE FAMOUS MARITIME EXPLORER}

After his father's death, Jean-Baptiste Charcot inherited a considerable sum, which allowed him to embark on his seaborne adventures ${ }^{1,2,8}$.

Having decided to explore the polar region, he first visited the Arctic, to which he made several expeditions, gaining an enviable reputation for scientific investigation. The British Royal Navy officer and the Antarctic explorer Robert Scott referred to him as the 'Polar Gentleman'2,8,10.

In 1896, Jean-Baptiste married the granddaughter of the famous writer Victor Hugo, Jeanne Hugo, but sadly the marriage was to become a nightmare for both and to end after his wife sought a divorce ${ }^{8,10}$.

After France became interested in setting up the project known as "The French Antarctic Expedition", Jean-Baptiste Charcot obtained financial support from the government as well as several societies to start his activities as a maritime explorer in the South Pole, known at that time as the great Terra Incognita ${ }^{10}$.

The first expedition to the Antarctic polar ice cap (from 1904 to 1907) traveled on the famous ship Français, and the second (from 1908 to 1910) on Pourquoi Pas? (Fig 2) ${ }^{10}$.

The expedition to the Antarctic on the Français was highly successful, resulting in the discovery of almost 620 miles

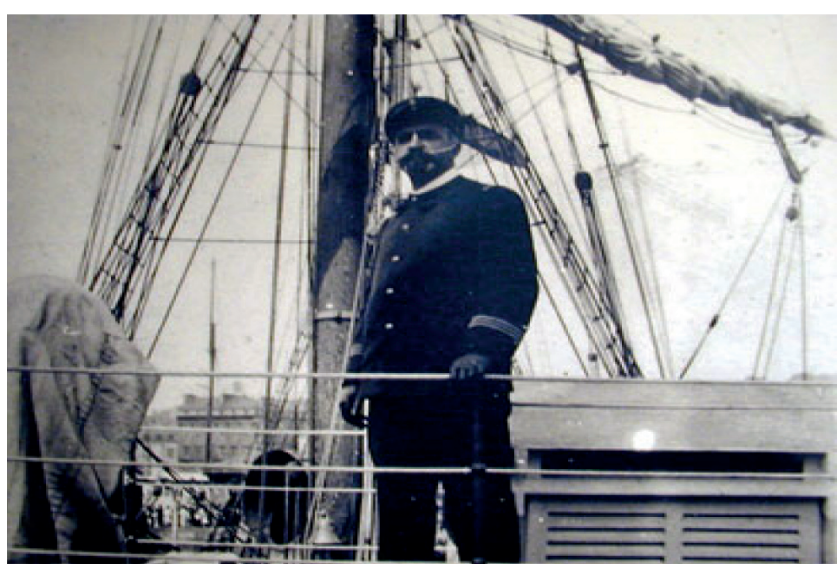

Extracted from Google Images. Coolantarctica.com.

Fig 2. Jean-Baptiste Charcot (1867-1936) at Pourquois Pas?.

of coasts and islands, and a map of the region was produced. After this expedition, Jean-Baptiste became a true star, a new hero, known as "Commandant Charcot"10.

The second French Antarctic expedition aboard the ship Pourquoi Pas? received considerable support from the French government and left Le Havre on August 15, 1908, with a crew of 22, including Commander Charcot's new wife, Marguerite or $\mathrm{Meg}^{10}$.

Although a huge success, the expedition encountered several problems. The first one was very similar to the incident that befell the expedition with the Français (the ship hit a submerged rock), and the second, which occurred after this, involved a disease that affected various members of the crew (scurvy) ${ }^{10}$.

The diary of the second French expedition to the South Pole was published as 'The voyage of the 'Pourquoi Pas?' in the Antarctic ${ }^{10}$ ".

In 1936, Jean-Baptiste, who was by then 69 years-old, embarked on a trip to Northern Iceland aboard Pourquoi Pas? This was to prove his last, as on September 15, the ship was caught in a violent storm and sunk off the coast of Iceland ${ }^{2}$.

Commander Charcot went down with the ship, and only one crew member survived. His body was recovered and was buried in Montmartre Cemetery, where his father and mother had been buried ${ }^{2}$.

\section{DISCUSSION}

Professor Jean-Martin Charcot encouraged his son to become a physician and a neurologist, but this career was unattractive to Jean-Baptiste, who tried to escape from the shadow of his father ${ }^{1,2,8,10}$.

After his father's death, in 1893, Jean-Baptiste gave up his medical activities and created his own destiny 
becoming a maritime explorer. At the time, he said, "If I succeed, that would be the best way to honor the memory of my father, because the name of Charcot would be honored twice", ${ }^{\prime 210}$.

The first, and particularly the second, Antarctic expedition, brought Commander Charcot tremendous fame because of the great achievements these expeditions represented for France and the world.

There are several landmarks in the Antarctica that bear the Charcot name, most notably Charcot Island, named in homage to Jean-Baptiste's father ${ }^{10}$.
In conclusion, the Charcot name became very famous around the world, firstly because of the work of Professor Jean-Martin Charcot, the founder of Clinical Neurology, and secondly because of his son, Jean-Baptiste, the world famous maritime explorer.

\section{ACKNOWLEGDMENTS}

The authors would like to thank Dr. Plínio M. Lima for his kind support.

\section{References}

1. Goetz CG, Bonduelle M, Gelfand T. Charcot. Constructing Neurology. New York: Oxford University Press; 1995.

2. Bailey P.J-M. Charcot. 1825-1893. His Life - His Work, Georges Guillain. New York: Paul B. Hoeber Inc.; 1959.

3. Guinon G. Charcot Intime. Paris Medical 1925;56:511-516.

4. Souques A. Charcot Intime. La Presse Medicale 1925;42:693-698.

5. Bonduelle M. The intimate Charcot. Rev Neurol (Paris) 1994;150:524-528.

6. Signoret JL. Une leçon clinique à La Salpêtrière (1887) par Andrè Brouillet. Rev Neurol (Paris) 1983;139:687-701.
7. Debove M. Eloge de JM. Charcot. Gaz Hop 1900;20:1545-1553.

8. Charcot JB. Discours du 19 novembre. 1907. Fr Med 1907;435-436.

9. Walusinski O. Jean-Martin Charcot's house officers at La Salpêtrière Hospital. In: Bogusslavsky J. Following Charcot: a forgotten history of neurology and psychiatry. Frontiers of neurology and neuroscience. Volume 29. Karger: Montreux; 2011; 9-35.

10. Charcot JB. The voyage of the "Why Not? The Journal of the second French South Polar Expedition, 1908-1910. Translation by Philip Walsh. University of Toronto Library: The Musson Book Company Limited; 1980. 